\title{
Amblyomma nodosum (Acari: Ixodidae) parasitizing a domestic dog in Colatina, Espírito Santo, Brazil
}

\author{
Carrapato Amblyomma nodosum (Acari: Ixodidae) parasitando cão em um \\ domicílio de Colatina, Espírito Santo, Brasil \\ Rafael Maziolii'; Matias Szabó² Cláudio Mafra ${ }^{1 *}$
}

${ }^{1}$ Departamento de Bioquímica e Biologia Molecular, Universidade Federal de Viçosa - UFV, Viçosa, MG, Brasil

${ }^{2}$ Faculdade de Medicina Veterinária, Universidade Federal de Uberlândia - UFU, Uberlândia, MG, Brasil

Received August 21, 2012

Accepted October 15, 2012

\begin{abstract}
On 27 Jan 2011 an adult Amblyomma nodosum tick was found attached to a domestic dog from the municipality of Colatina, state of Espírito Santo, Brazil. This is the first report of this tick species in this state and the second time it has been reported parasitizing a domestic dog in the country. For the time being, this finding should be regarded as incidental. However, more in-depth research into the hosts and ecology of $A$. nodosum is needed, since it has been associated to infectious agents that are potentially pathogenic for humans.
\end{abstract}

Keywords: Dog, Amblyomma nodosum, Espírito Santo, Brazil, parasitism.

\section{Resumo}

Em 17 de janeiro de 2011 um carrapato adulto de Amblyomma nodosum foi encontrado parasitando um cão doméstico no município de Colatina, Espírito Santo, Brasil. Esta é a primeira vez que esta espécie de carrapato foi descrita no Estado e pela segunda vez no país parasitando um cáo doméstico. Este achado por ora deve ser considerado fortuito. Entretanto, a busca por informaçôes adicionais sobre hospedeiros e ecologia do A. nodosum é recomendada uma vez que este parasito já foi associado a agente infeccioso potencialmente patogênico para seres humanos.

Palavras-chave: Cão, Amblyomma nodosum, Espírito Santo, Brasil, parasitismo.

Ticks are cosmopolitan ectoparasites, major infectious diseases vectors, and the geographic distribution of species is driven by both host and environmental requirements. Amblyomma nodosum Neumann, 1899 is a Neotropical tick species widely distributed throughout Argentina, Bolivia, Brazil, Colombia, Costa Rica, Guatemala, Guiana, Mexico, Nicaragua, Panama, Trinidad and Tobago, and Venezuela (IVANCOVICH, 1987; JONES et al., 1972; KEIRANS; BREWSTER, 1981). This tick species was first reported in Brazil by Aragão (1911) and has since then been found in several states of the country such as Goiás, Mato Grosso do Sul, Mato Grosso, Minas Gerais, Paraná, Rio de Janeiro, Rondônia, Rio Grande do Sul and São Paulo (ARAGÃO, 1936; ARZUA et al., 2005; BECHARA et al., 2002; CAMPOS PEREIRA et al., 2000; EVANS et al., 2000; LABRUNA et al., 2005; MARTINS et al., 2004). Larvae and nymphs of $A$. nodosum are mostly found on birds of several species (JONES et al., 1972; LABRUNA et al., 2007; OGRZEWALSKA et al., 2009a), whereas adults have a more restricted host range involving mainly members of the family

\footnotetext{
${ }^{*}$ Corresponding author: Cláudio Mafra

Departamento de Bioquímica e Biologia Molecular, Universidade Federal de

Viçosa - UFV, CEP 36570-000, Viçosa, MG, Brasil

e-mail:mafra@ufv.br
}

Myrmecophagidae such as the Southern Tamandua (Tamandua tetradactyla) and the Giant Anteater (Myrmecophaga tridactyla) (CAMPOS PEREIRA et al., 2000; GUGLIELMONE et al., 2003; ARZUA et al., 2005). These hosts, however, are found in all Brazilian biomes (PAGLIA et al., 2012). We herein report the case of a domestic $\operatorname{dog}$ with an adult $A$. nodosum tick attached to it; to the best of our knowledge, this occurrence is the first in the state of Espírito Santo and the second in Brazil. On 17 Jan 2011 an adult tick was found attached to a domestic dog in Colatina, Espírito Santo, Brazil (19 $32^{\prime} 20^{\prime \prime} \mathrm{S}$ and $\left.40^{\circ} 37^{\prime} 51^{\prime \prime} \mathrm{W}\right)$. The tick differed noticeably from the Rhipicephalus sanguineus ticks regularly found on the $\operatorname{dog}$ and was identified as a male $A$. nodosum, according to the taxonomic key for adult Amblyomma (Onofrio et al., 2006). The dog, a male Belgian Shepherd weighing $37 \mathrm{~kg}$, belonged to one of the authors (RM) and was nine years old at the time. It lived with an adult female of the same breed and they were restricted to the owner's house and garden. The city of Colatina, population 111,188, is located in the north of the state on the banks of the Doce River (IBGE, 2010). The municipality still has a few fragments of Atlantic rainforest, its original vegetation. The dogs were occasionally taken for walks but never to forested areas. Several animals have been found in this garden, such as 
toads, bats, cats, small rodents, and porcupines. Albeit never seen inside the house, opossums have been reported in that area. The owner, an amateur ornithologist, has also identified 25 different bird species in his garden. Such a variety of bird species is attracted from neighboring areas and from rainforest fragments by a mango tree (Mangifera indica L.) in the garden, and by various fruits the owner regularly provides for the birds. We speculate that the adult tick found on the dog was brought to the garden as an immature form on a bird as previously noted in other area (TOLESANOPASCOLI et al., 2010). At the same time it has been described previously from dogs only once in Brazil (SABATINI et al., 2010). Birds may actually deliver ticks the other way round, picking them up in rural/urban areas (SZABÓ et al., 2008). This linking ability of birds is possibly encouraged by human activities such as, in the case reported here, the owner's bird feeding habit, which is very common human behavior. Whatever the case, bridging vectors from natural areas increases the likelihood of human and domestic animal infection. Ogrzewalska et al. (2009b) reported Rickettsia parkeri from $A$. nodosum ticks picked from birds. Thus, further research on the biology and ecology of this tick species is important to determine if our finding is incidental or represents an ongoing trend. Should it be proven to be a trend, awareness is warranted. In this case, existing dog-human bonds may provide a link for the transmission of infectious disease.

\section{References}

Aragão HB. Notas sobre ixódidas brazileiros. Mem Inst Oswaldo Cruz 1911; 3(2): 145-195. http://dx.doi.org/10.1590/S007402761911000200001

Aragão HB. Ixodidas brasileiros e de alguns paizes limitrophes. Mem Inst Oswaldo Cruz 1936; 31(4): 759-843. http://dx.doi.org/10.1590/ S0074-02761936000400004

Arzua M, Onofrio VC, Barros-Battesti DM. Catalogue of the tick collection (Acari: Ixodida) of the Museu de História Natural Capão da Imbuia, Curitiba, Paraná, Brazil. Rev Bras Zool 2005; 22(3): 623-632. http://dx.doi.org/10.1590/S0101-81752005000300015

Bechara GH, Szabó MPJ, Almeida-Filho WV, Bechara JN, Pereira RJ, Garcia JE, et al. Ticks associated with armadillo (Euphractus sexcinctus) and anteater Myrmecophaga tridactyla) of Emas National Park, state of Goias, Brazil. Ann N Y Acad Sci 2002; 969: 290-293. PMid:12381607. http://dx.doi.org/10.1111/j.1749-6632.2002.tb04394.x

Campos Pereira M, Szabó MPJ, Bechara GH, Matushima ER, Duarte JM, Rechav Y, et al. Ticks (Acari: Ixodidae) associated with wild animals in the Pantanal region of Brazil. J Med Entomol 2000; 37(6): 979-983. http://dx.doi.org/10.1603/0022-2585-37.6.979

Evans DE, Martins JR, Guglielmone AA. A review of the ticks (Acari, Ixodida) of Brazil, their hosts and geographic distribution - 1 . The state of Rio Grande do Sul, southern Brazil. Mem Inst Oswaldo Cruz 2000; 95(4): 453-470. PMid:10904399. http://dx.doi. org/10.1590/S0074-02762000000400003

Guglielmone AA, Estrada-Peña A, Keirans JE, Robbins RG. Ticks (Acari: Ixodidae) of the neotropical zoogeographic region. Houten: International Consortium on Ticks and Tick-borne Diseases; 2003.
Instituto Brasileiro de Geografia e Estatística - IBGE.Cidades@ [online]. 2010 [cited 2012 Ago 19]. Available from: http://www.ibge. gov.br/cidadesat/painel/painel.php?codmun=320150\#.

Ivancovich JC. Amblyomma nodosum Neumann, 1899 (Acarina - Ixodidae), nueva especie de garrapata en Argentina. Vet Arg 1987; 4: 150-153.

Jones EK, Clifford CM, Keirans JE, Kohls GM. The ticks of Venezuela (Acarina: Ixodoidea) with a key to the species of Amblyomma in the Western hemisphere. Brigham Young Univ Sci Bull Biol Ser 1972; 17(4): 1-40.

Keirans JE, Brewster BE. The Nuttal and British Museum (Natural History) tick collections: lectotype designations for ticks (Acarina: Ixodoidea) described by Nuttal, Warburton, Cooper and Robinson. Bull Brit Mus (Natur Hist) Zool 1981; 41(4): 153-178.

Labruna MB, Camargo LMA, Terrassini FA, Ferreira F, Shumaker TTS, Camargo EP. Ticks (Acari: Ixodidae) from the state of Rondônia, western Amazon, Brazil. Syst Appl Acarol 2005; 10: 17-32.

Labruna MB, Sanfilippo LF, Demetrio C, Menezes AC, Pinter A, Guglielmone AA, et al. Ticks collected on birds in the state of São Paulo, Brazil. Exp Appl Acarol 2007; 43(2): 147-160. PMid:17882514. http:// dx.doi.org/10.1007/s10493-007-9106-x

Martins JR, Medri IM, Oliveira CM, Guglielmone AA. Ocorrência de carrapatos em tamanduá-bandeira (Myrmecophaga tridactyla) e tamanduámirim (Tamandua tetradactyla) na região do Pantanal Mato-Grossense, Brasil. Cien Rural 2004; 34(1): 293-295. http://dx.doi.org/10.1590/ S0103-84782004000100048

Ogrzewalska M, Pacheco R, Uezu A, Richtzenhain LJ, Ferreira F, Labruna MB. Ticks (Acari: Ixodidae) infesting birds in an Atlantic rain forest region of Brazil. J Med Entomol 2009a; 46(5): 1225-1229. PMid:19769058. http://dx.doi.org/10.1603/033.046.0534

Ogrzewalska M, Pacheco RC, Uezu A, Richtzenhain LJ, Ferreira F, Labruna MB. Rickettsial infection in Amblyomma nodosum ticks (Acari: Ixodidae) from Brazil. Ann Trop Med Parasitol 2009b; 103(5): 413-425. PMid:19583912. http://dx.doi.org/10.1179/136485909X451744

Onofrio VC, Labruna MB, Pinter A, Giacomin FG, Barros-Battesti DM. Comentários e chaves para as espécies de Amblyomma. In: Barros-Battesti DM, Arzua M, Bechara GH. Carrapatos de importância médico-veterinária da regiāo neotropical: um guia ilustrado para identificação de espécies. São Paulo: Vox/ICTTD-3/Butantan; 2006. p. 53-71.

Paglia AP, Fonseca GAB, Rylands AB, Herrmann G, Aguiar LMS, Chiarello AG, et al. Lista Anotada dos Mamiferos do Brasil. 2 ed. Arlington: Conservation International; 2012.

Sabatini GS, Pinter A, Nieri-Bastos FA, Marcili A, Labruna MB. Survey of ticks (Acari: Ixodidae) and their Rickettsia in an Atlantic Rain Forest reserve in the State of São Paulo, Brazil. J Med Entomol 2010; 47(5): 913-916. PMid:20939390. http://dx.doi.org/10.1603/ME10073

Szabó MPJ, Pascoli GVT, Marçal Júnior O, Franchin AG, Torga K. Brown dog tick Rhipicephalus sanguineus parasitizing the bird Coereba flaveola in the Brazilian Cerrado. Cienc Rural 2008; 38(2): 543-545. http://dx.doi.org/10.1590/S0103-84782008000200041

Tolesano-Pascoli GV, Torga K, Franchin AG, Ogrzewalska M, Gerardi $\mathrm{M}$, Olegário MMM, et al. Ticks on birds in a forest fragment of Brazilian cerrado (savanna) in the municipality of Uberlândia, State of Minas Gerais, Brazil. Rev Bras Parasitol Vet 2010; 19(4): 244-248. PMid:21184702. http://dx.doi.org/10.1590/S1984-29612010000400010 